\title{
How Internet Shutdowns Affects the Entrepreneurs in Jammu and Kashmir
}

\author{
Shahid Qadir, Desh Bhagat University, India \\ Amir Ahmad Dar, B. S. Abdur Rahman Crescent Institute of Science and Technology, India
}

\begin{abstract}
Entrepreneurship is the globally accepted source for economic development in underdeveloped countries like India and Pakistan. The internet is used as a business resource for growth and development. The internet is a global network that provides information and communication facilities. Shutdown of internet services has become a common trend in Jammu and Kashmir to stop rumors and misinformation sharing on social media applications. But it affects the economy and social life of people living in Jammu and Kashmir. Shutdown of internet has become common in Jammu and Kashmir after the militants used social media as a tool for recruiting the young generation. Government of Jammu and Kashmir snapped internet services whenever any anti-military and antigovernment operation happened. Continued shutdown of internet in the region results in winding up small business unit, which operates through internet. This paper particularly focused on how internet shutdowns affect the entrepreneur and which problems are faced by entrepreneurs in Jammu and Kashmir by the shutdown of internet in the area.
\end{abstract}

\section{KEYWORDS}

E-Terrorists, Entrepreneur, Entrepreneurship, Enterprise, Internet Shutdowns, Rumors

\section{INTRODUCTION}

Internet is a global computer network provides a variety of information and communication facilities. It is perhaps the most useful source for obtaining the latest information, which may otherwise till be a month away to appear in the print form (Gagan \& Rakesh, 2013). The Internet has become an essential requirement for day to day life. Today the internet is required in every field whether business, studying or any other thing. Internet is required whether you have to order food or have to do any banking transaction or have to contact with your clients, customers, or any other person. The Internet has changed the global business from marketing to advertisement, purchasing to selling, finance to human resources, etc. in the present times, we have live examples of Google, Amazon, Flipkart, etc companies which are touching the stars with the help of internet. But on the other side internet has also few drawbacks like security problems, e-terrorists, etc which is a threat for entrepreneurs while operating business online globally.

An entrepreneur can be defined as a person who takes the initiative to start a business. In other words, it can be defined as a person who invests finance in order to earn profits is known as an entrepreneur. It is an entrepreneur who brings new products and services to the market, while people 
access these products and services for their use and benefit. It is an entrepreneur who has the ability to translate ideas into actions. While as Entrepreneurship is a process performed by an Entrepreneur while operating an Enterprise. Entrepreneurship is the lifeblood of any economic development. The more entrepreneurship activities the more will be the economic development. Entrepreneurship is the most effective tool to fulfill the needs and demands of society. Enterprise can be defined as a business unit or firm on which an entrepreneur invest money. Entrepreneurship plays an important role in the economic development of a country. Entrepreneurs provide jobs to the millions of people around the country and worldwide which increases the standard of living of the people of a country and solves the main issue of people I.e., Poverty.

A shutdown of the internet has become common in Kashmir. Government suspends internet services there in order to control the spread of rumors, misinformation and to maintain laws and orders to prevent violences. As per the different estimates used in the study, the total duration of shutdowns in India between 2012 and 2017 remains 16,315 hours (680 days), which has generated an economic loss of approximately $\$ 3.04$ million (Rydzak, 2019). An Internet shutdown is an intentional disruption of internet or electronic communications, rendering them inaccessible or effectively unusable, for a specific population or within a location, often to exert control over the flow of information (Sflc, 2018). In the year 2016, the internet was suspended for more than 6-month s (08 July 2016 to 17 January 2017 on prepaid services and 08 July 2016 to November 16, 2016, 0n postpaid services) after the death of Burhan wani (a local rebel) by security forces. In these six months Kashmir economy affects a lot in all sectors whether tourism, transportation, traders, etc. a recent international study has said that the Kashmir is the region with highest number of internet shutdown in the world it has stated that Kashmir economy witnessed Rs 1776crore losses due to internet shutdown in 2017(ICRIER Report). In the area of Jammu and Kashmir, most of the entrepreneurs are affected by the internet because of the long shutdown of the internet from the past couple of years, which affects the entrepreneurs while operating their business. In 2016 and 2017 the countries that experience the largest number of unexpected internet shutdowns were India, Iraq, Syria, Pakistan Turkey and Brazil (Shandler, 2018). In recent studies, Jammu and Kashmir is the most internet shutdown state in India from the last few years because of strikes and shutdowns in Jammu and Kashmir from the last couple of years. These strikes and shutdowns result in long time shutdowns of the internet which affects the life of entrepreneurs and students in the area of Jammu and Kashmir India. In 2017, the number of internet shutdowns in India more than doubled from 2016, while the total hours of a shutdown increased by only 20 percent (Kathuria et al. 2018). Entrepreneurs face problems like transfer of documents and receipts, money transfer, online access, obtaining necessary information through the internet, etc. Jammu and Kashmir is the area which has very low private business ventures which results from low development, more unemployment, low economic development, etc. in the state of Jammu and Kashmir where already industrial sectors is low are much affected by the shutdown of internet. From the past couple of years in Kashmir, internet services are worst which affected the entrepreneurs to connect with their clients and other parties for their business requirements. Almost everyone is Jammu and Kashmir are badly affected by the shutdown of internet especially students and entrepreneurs. Students face various problems regarding studies and entrepreneurs who engaged with internet cafe and tourism are badly affected by the shutdown of the internet in the Jammu and Kashmir. The five-day telecommunications and internet services shutdown in Egypt in 2011 costs Egypt's economy at least us $\$ 90$ million (Wagner, 2018). The total number of temporary disruptions by country from $1^{\text {st }}$ July 2015 to $30^{\text {th }}$ June 2016 . Overall, there were 81 disruptions in 19 countries during this period this include 22 in India, 22 in Iraq, 08 in the non-isis controlled parts of Syria, 6 in Pakistan, 3 in turkey, and 2 each in Bangladesh, Brazil, North Korea, Republic of the Congo, Uganda, and Vietnam, among other places. The total economic impact of internet disruptions, both in terms of the number of days and GDP lost. A total of at least us $\$ 2.4$ billion over the past year, with impact ranging from us $\$ 968$ million in India to us $\$ 313,666$ in North Korea these disruptions lasted 753 days in total across all countries (West, 2016). 
The following are the main objectives of the research paper:

1. To study how internet shutdown affects the entrepreneurs in Jammu and Kashmir;

2. To study the various problems faced by entrepreneurs by the shutdown of the internet.

\section{RESEARCH METHODOLOGY}

The research paper is based on both primary and secondary data. The primary data is collected through face to face interview with entrepreneurs and students of Jammu and Kashmir (questionnaire is mentioned at the end i.e. Appendix part Table 1), and secondary data is collected from various published papers (Ahmad et al. 2016; Gagan \& Rakesh, 2013)).

\section{ENTREPRENEURSHIP IN JAMMU AND KASHMIR}

The concept of entrepreneurship is not new, the first academic use of the word by an economist was likely in 1730 by Richard Cantillion, Entrepreneurship can be defined as the capacity and willingness to develop, organize and manage a business venture in order to make a profit (Long, 1983). The common example of entrepreneurship is the starting of a new business. Entrepreneurship focuses on the management within a small but highly successful division of an automotive manufacturing firm and considers competitiveness strategy labor markets organizational politics (Stewart, 1989). Unemployment is the most common problem faced in Jammu and Kashmir. The state and central government along with various financial institution like JKEDI (Jammu and Kashmir entrepreneurship development institute), District Employment Exchanges, etc. help to develop entrepreneurship in Jammu and Kashmir in order to cope up with the problem of unemployment (Ahmad, 2018). Both male and female young and energetic young entrepreneurs contributing their maximum in order to develop entrepreneurship in Jammu and Kashmir by motivating educated unemployed youth of Jammu and Kashmir. Entrepreneurship Development Institute of Jammu and Kashmir helping educated youth with great potential by motivating and providing training and financial assistance to the young entrepreneurs in Jammu and Kashmir. J\&K bank ltd also helping young entrepreneurs by providing financial assistance for their business which is the lifeblood for every business. Every year JKEDI provides training to the thousands of new entrepreneurs which includes both male and female in Jammu and Kashmir. JKEDI has become the most valuable source for educated youth in Jammu and Kashmir who wants to become an entrepreneurs, JKEDI helps them in every step of their business from training to finance. Entrepreneurs in Jammu and Kashmir faces various problems like lack of social and family support, lack of capital and discouraging response of credit providing agencies like banks and other financial institutions, lack of inadequate and necessary physical infrastructure, lack of skill development institutes providing and creating necessary skill and attitude required to a successful entrepreneur, lack of necessary and timely government support, lack of adequate technology and technological advancements are the major problems faced by the new and young energetic entrepreneurs for being a successful entrepreneur in Jammu and Kashmir (Ahmad et al., 2016). These problems are not yet solved another most common barrier/problem exists from the last couple of years that's Internet shutdowns which affect almost every person in Jammu and Kashmir who are associated with business, study, research, etc. shutdown of internet services and imposed restrictions in Jammu and Kashmir had impact the social life of people. Thousands of private sectors employees had lost their jobs because of restriction in Jammu and Kashmir. In other parts of world internet is used as a source of income but here no availability of continuous internet facility makes the life difficult. 


\section{PROBLEMS FACED BY ENTREPRENEURS BY SHUTDOWN OF INTERNET IN JAMMU AND KASHMIR}

The basic problems faced by Entrepreneurs by the shutdown of internet services in Jammu and Kashmir are as follow:

- Unable to send necessary documents.

- Unable to Access online services.

- The problem in finding the necessary information.

- Unable to transfer online money.

- Loss of customers.

- Loss of jobs/employees/workers.

\subsection{Unable to Send Necessary Documents}

An Entrepreneur is unable to send necessary documents and information from one person to another through email or any other online services without an internet connection. Entrepreneurs operating their business in the area of Jammu and Kashmir where mostly internet services are snapped by the government faces the problems in sending necessary documents and information to their clients and suppliers or other persons. Blocking of the internet in Jammu and Kashmir creates various problems for the people of $\mathbf{J} \& \mathrm{~K}$ especially Entrepreneurs and students. Entrepreneurs need to travel various kilometers in order to send bills and documents through courier which is costly and time-consuming rather than send online through email and other online services. People need to travels various kilometers in order to confirm online orders and send necessary documents.

\subsection{Unable to Access Online Services}

Online business had changed the business style in the business world. In the modern time almost each and every thing is available on internet. Online services are becoming common in our day to day life. A person can buy anything through online mode with the help of the internet same as an entrepreneur can buy or sell products online with the help of internet services. If internet services are not available then an entrepreneur can't access these facilities. Same is the case as in Kashmir region where internet services are suspended for a long time period of time by which entrepreneurs can't access online services, which are fast and easy to use. Various online shopping sites had suspended their services in Kashmir region due to continuous shutdown of internet services.

\subsection{The Problem in the finding Necessary Information}

Internet has become primary and easy source of getting latest information in each and every field. A person can easily get information regarding business and other fields with the help of internet. In Jammu and Kashmir where internet services are suspended most from the last couple of years, it is difficult to find information on the internet all the time. Entrepreneurs and local people face lots of problems while searching for information through the internet. After the abrogation of article 370 on $5^{\text {th }}$ August 2019 (which was giving special status for the people of Jammu and Kashmir) all the internet services was suspended in whole Jammu and Kashmir which was suspended till 25 January 2020 only $2 \mathrm{G}$ services was restored and high speed internet is still suspended in Kashmir region as on $15^{\text {th }}$ June 2020. This is the longest internet shutdown in the world. During this period of internet suspension each and every person is facing problems in Kashmir region. Students was unable to attend online classes. Entrepreneurs was unable to operate online business due to lockdown because of covid-19. 


\subsection{Unable to Transfer Money Online}

Money can easily transfer from one bank account to another through e-banking with the help of the internet without going to the branch which saves lots of time. An entrepreneur always deals with money whether with supplier or buyer or may have employees or any other agency. Almost every bank have their online application for online transactions (like J\&K bank has mpay, HDFC Bank have HDFC Bank App. Etc) through which money can be transfer from one account to another with the help internet facility. In $J \& K$ where internet services are suspended which results entrepreneurs can't transfer money from one account to another in those days. Which leads them a waste of time while going to the branch to transfer money and to stand in a queue. Having not availability of internet it increases the risk in carrying much amount of cash in hand. Internet facility decreases the risk in carrying cash in hand.

\subsection{Loss of Customers}

Jammu and Kashmir is famous for number of tourist destinations. In Jammu and kashmir tourism has a wide scope because a large number of tourists visit jammu and kashmir every year to enjoy their holidays and trips. In Jammu and kashmir there are large number of hotels in tourist places which offers online services (booking of the room, online cash payments). These services can access only through the internet. If the internet facility is not available then customer can't access these services, which result in the loss of customers to the hotels. Same is the case with internet café owners their services are totally dependent upon the internet. In Jammu and Kashmir where the internet is mostly suspended results loss of customers to the internet cafe business entrepreneurs which leads them towards losses. The violence in Jammu and Kashmir has hit tourism, one of the most important sectors for the state economy. Tourist arrivals have gone down from 12,000 to 250 per day and hotel occupancy is around 3 percent on Aug. 2016 due to the complete lockdown for months after the killing of poster boy Burhan wani. Shutdown of internet in leads the people of Jammu and Kashmir towards losses. It overall impacts on state economy of Jammu and Kashmir. Due to the complete restrictions in Jammu and Kashmir in 2016 the tourists who had pre booking their bookings for Kashmir travel has cancelled their bookings which leads the tourist sectors down.

\subsection{Loss of Jobs/Workers/Employees}

Employees who was working in IT field and who are associated with online business services has most threat of losing jobs due of suspension of internet services in Jammu and Kashmir. Most of educated youth are unemployed here due to lack of private sector especially in Kashmir region because of disturbance area. During the crises in 2016 thousands of educated youth lost their jobs who was working in private sector especially in hotel and tourism. Due to complete restrictions for almost six months almost all the private industries had shut their working for almost six months. Same is case repeating here due to lockdown because of covid-19, large number of employees had losses their jobs in private sector not only in jammu and Kashmir but worldwide. Sometimes entrepreneurs loss their workers and employees who are important for business, due to complete restrictions people can't travel from one place to another. So the employees and workers cannot go for work as they stayed at their homes.

\section{CONCLUSION}

The main purpose of the paper is to find how internet shutdown affects the entrepreneurs in Jammu and Kashmir India and which problems are faced by the Entrepreneurs in Jammu and Kashmir by the shutdown of Internet services in the State. The result deficits that the entrepreneurs who are most engaged with IT and tour \& travels are mostly affected with the shutdown of the internet from the past couple of years in the Jammu and Kashmir, because their business is dependent on the internet as 
shown in figure 1 . Those entrepreneurs who are engaged with manufacturing and retailer faces fewer problems rather than others and those entrepreneurs who had trade links with outside Jammu and Kashmir also greatly affected. Jammu and Kashmir have the various number of tourists destinations which results hotels are greatly affected because tourists are unable for pre-booking rooms and various other services. Various online shopping sites had stopped delivering products in various regions of Kashmir region. Rather than entrepreneurs, students and common people also affected by the shutdowns of the internet in Jammu and Kashmir.

\subsection{Suggestions}

During the study, it was found that the entrepreneurs of Jammu and Kashmir are facing various problems by the shutdown of the internet which affects their business negatively. To overcome these problems the government of India must have come on a solution or finds an alternative so that the internet will not be shutdown in the Jammu and Kashmir. They can shutdown social media applications rather than shutdown the internet in the valley. If they will shutdown only social media apps during the restrictions in the valley it will result that the entrepreneurs and students can easily access the internet for their requirement without affecting others. During the studies it was found that government shutdown internet facilities in order to prevent spread rumors, misinformation. Which is mostly spread on social media. if the social media will be suspended during the restrictions in Jammu and Kashmir it will help to prevent spread of rumors without effecting common people for accessing access internet facilities for education, business and other activities.

Further examinations may consider about the use of a few models in setting up the connection between the variables for example design of experiment (as in Dar and Auradha 2018a; Dar and Anuradha 2018b; Dar and Anuradha 2018c).

Figure 1. Shows the firms effected by shutdown of internet services in Jammu and Kashmir

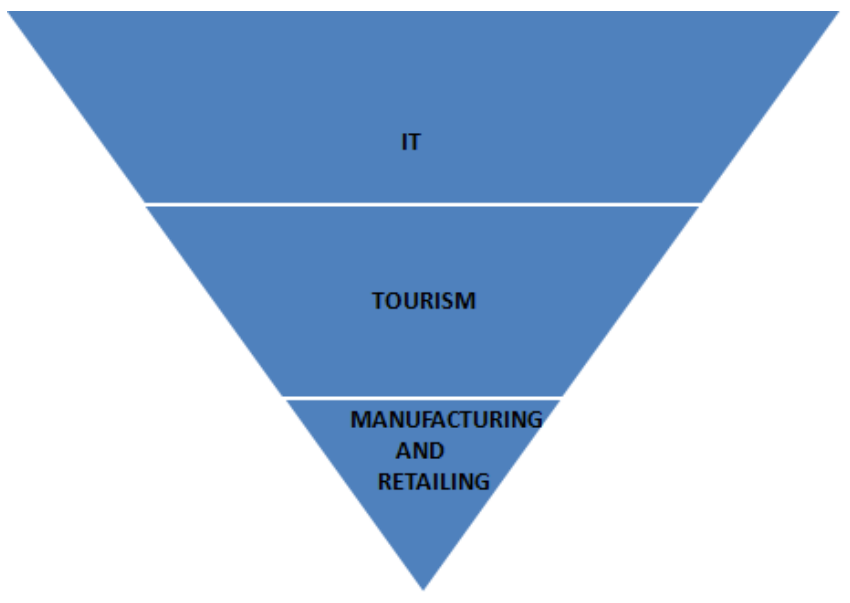




\section{REFERENCES}

Ahmad, M., Bhat, B. H., Bhat, S. A., \& War, M. A. (2016). A Study on the Problems of Entrepreneurs in Jammu and Kashmir. International Journal of Commerce and Business Management, 5(2), 269-273.

Ahmed, A. (2018). Problem and performance of Entrepreneurship Development and Start-Ups in Jammu and Kashmir. International Journal of Innovative Knowledge Concepts, 6(9).

Dar, A., \& Anuradha, N. (2018). Use of orthogonal arrays and design of experiment via Taguchi L9 method in probability of default. Accounting, 4(3), 113-122.

Dar, A. A., \& Anuradha, N. (2018). An application of Taguchi L9 method in Black Scholes model for European call option. International Journal of Entrepreneurship.

Dar, A. A., \& Anuradha, N. (2018). Effects of parameters on Black Scholes Model for European put option using Taguchi L27 Method. International Journal of Pure and Applied Mathematics, 119(13), 11-19.

Gagan, S., \& Rakesh, P. (2013). Use of internet for research and educational activities by research scholars: A study of DSB Campus of Kumaun University-Nainital. Int J Eng Manuf, 4(2), 193-199.

Kathuria, R., Kedia, M., Varma, G., Bagchi, K., \& Sekhani, R. (2018). The anatomy of an internet blackout: measuring the economic impact of internet shutdowns in India. Academic Press.

Long, W. (1983). The meaning of entrepreneurship. American Journal of Small Business, 8(2), 47-59.

Rydzak, J. (2019). Of Blackouts and Bandhs: The Strategy and Structure of Disconnected Protest in India. Available at SSRN 3330413

SFLC. (2018). Living in digital darkness - a handbook on internet shutdowns in india. SFLC Publication.

Shandler, R. (2018). Measuring the Political and Social Implications of Government-Initiated Cyber Shutdowns. In 8th \{USENIX\} Workshop on Free and Open Communications on the Internet. USENIX Association.

Stewart, A. (1989). The Team Entrepreneurship. Academic Press.

Wagner, B. (2018). Authoritarian Practices in the Digital Agel Understanding Internet Shutdowns: A Case Study from Pakistan. International Journal of Communication, 12, 22.

West, D. M. (2016). Internet shutdowns cost countries $\$ 2.4$ billion last year. Center for Technological Innovation at Brookings. 


\section{APPENDIX}

\section{Table 1. Questionnaire}

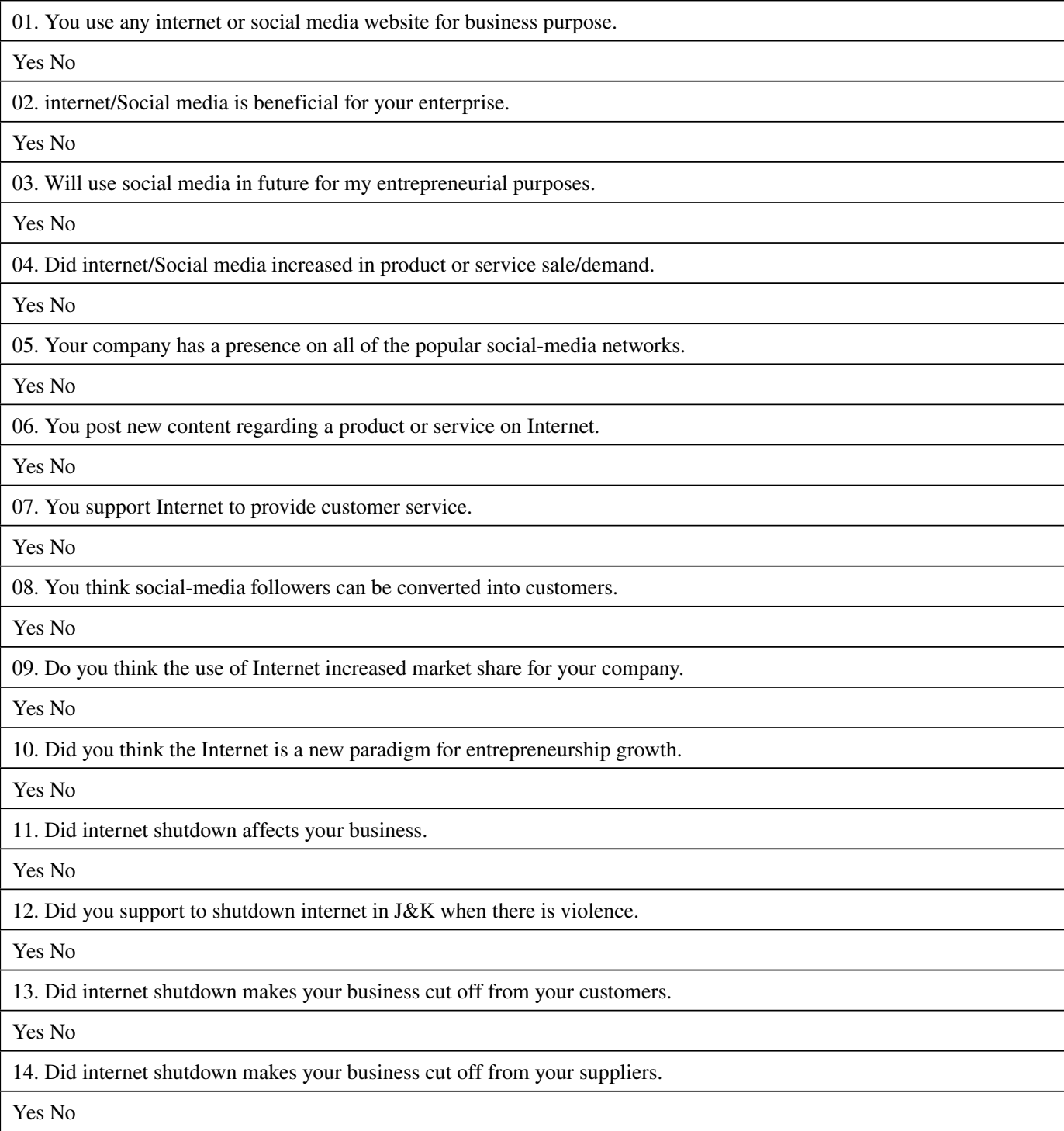

\section{List of Enterprises Visted}

1. Bhat rice mills

2. Dar handicarts

3. Local wholesalers and retailers

4. Noorani educational institute

5. Khidmat center

6. Wanposh wood factory 